\title{
Fusion of protoplasts with irradiated microprotoplasts as a tool for radiation hybrid panel in citrus
}

\author{
Claudine Maria de Bona( ${ }^{(1)}$, David Stelly(2), J. Creighton Miller Jr. ${ }^{(3)}$ and Eliezer Silva Louzada(4)
}

(1)Instituto Agronômico do Paraná (lapar), Rua Máximo João Kopp, no 274, Bloco 1, Ala Sul, Centro Administrativo do Governo do Estado, Santa Cândida, CEP 82630-900 Curitiba, PR, Brazil. E-mail: debona@iapar.br (2)Texas A\&M University (Tamu), Department of Soil \& Crop Sciences, College Station, Texas, USA, 77843-2474. E-mail: stelly@tamu.edu (3)Tamu, Department of Horticultural Sciences, College Station, Texas, USA, 77843-2133. E-mail: jcmillerjr@tamu.edu ${ }^{(4)}$ Texas A\&M University - Kingsville (Tamuk), Citrus Center, Weslaco, Texas, USA, 78599. E-mail: elouzada@ag.tamu.edu

\begin{abstract}
The objective of this work was to combine asymmetric somatic hybridization (donor-recipient fusion or gamma fusion) to microprotoplast-mediated chromosome transfer, as a tool to be used for chromosome mapping in Citrus. Swinglea glutinosa microprotoplasts were irradiated either with 50, 70, 100 or 200 gamma rays and fused to cv. Ruby Red grapefruit or Murcott tangor protoplasts. Cell colonies were successfully formed and AFLP analyses confirmed presence of S. glutinosa in both 'Murcott' tangor and 'Ruby Red' grapefruit genomes.
\end{abstract}

Index terms: Citrus, Swinglea glutinosa, asymmetric somatic hybridization, gamma rays, hybrid cell lines, radiation hybrid mapping.

\section{Fusão de protoplastos com microprotoplastos irradiados como ferramenta para painel híbrido de radiação em citros}

\begin{abstract}
Resumo - O objetivo deste trabalho foi combinar hibridação somática assimétrica (fusão doador-recipiente ou fusão gama) e transferência cromossômica mediada por microprotoplastos como uma ferramenta para o mapeamento cromossômico em Citrus. Microprotoplastos de Swinglea glutinosa foram irradiados com doses de 50,70, 100 ou 200 raios gama e fusionados com protoplastos de pomelo cv. Ruby Red ou de tangor Murcott. Houve sucesso na formação de colônias de células, e a análise AFLP confirmou a presença de S. glutinosa nos genomas do tangor 'Murcott' e do pomelo 'Ruby Red'.
\end{abstract}

Termos para indexação: Citrus, Swinglea glutinosa, hibridação somática assimétrica, raios gama, linhagens de células híbridas, mapeamento de híbridos por radiação.

\section{Introduction}

Citrus breeders and geneticists around the world have long desired to improve linkage maps based on easily scored, neutral molecular markers that empower selection schemes (Talon \& Gmitter Junior, 2008). Asymmetric somatic hybridization (donor-recipient fusion or gamma fusion) holds promise for use in chromosome mapping (Wijbrandi, 1989; Yerle, 2004) and radiation hybrid (RH) mapping, initially developed for animal systems (Wardrop et al., 2002; Gao et al., 2006), and a powerful tool for mapping genomes. It presents great potential for use in plants, because the procedure may be applied to any species from which somatic hybrid cells can be made, and mapping panels can be obtained with relative ease (Masoudi-Nejad et al., 2005). Chromosome-specific applications formaize were reported by Riera-Lizarazu et al. (2000), who irradiated maize-oat addition lines to produce different fragments of maize chromosome 9. Kynast et al. (2002) extended this approach to a nearly complete set of oat-maize chromosome additions, and analyzed expression of maize genes in the oat genetic background. Gao et al. (2004, 2006) created asymmetric sexual interspecific hybrid lines for genome-wide radiation hybrid mapping in cotton.

Deletion mapping and radiation hybrid mapping rely on the principle that if two markers are further apart on the chromosome, they are more likely to be physically separated by a given irradiation dose, leading to differential loss/retention. By estimating the frequency of breakage, thus the distance between markers, it is possible to determine their order in a manner analogous to meiotic mapping (Cox 
et al., 1990). Supposedly, gene introgression would be more efficient using small portions of the donor genome instead of the whole genome, because it has been shown that transfer of small portions of the genome (1-2 chromosomes together with a small portion of cytoplasm) significantly reduces the destabilization of the acceptor cell (Yemets \& Blume, 2003). Microprotoplast-mediated chromosome transfer (MMCT), developed for mammalian cells by Fournier \& Ruddle (1977), adjusted for plants by Ramulu et al. (1996a, 1996b) and applied in citrus by Louzada et al. (2002), combined with gamma irradiation could be interesting, since chromosome breakage would be more efficient in microprotoplasts than in protoplasts. The primary reasons for this are the small size of the microprotoplasts, which contain only few chromosomes, and the mitosis arresting substances used during the microprotoplast isolation process inhibits spindle formation, causing chromosomes to scatter during cell division. Sequentially, an extremely high centrifugation speed induces formation of microprotoplasts containing few chromosomes surrounded by some cytoplasm (Zhang et al., 2006).

The objective of this work was to combine MMCT and gamma irradiation for introgression of donor chromosome pieces into a background cell as a possible first step for future use in radiation mapping in citrus.

\section{Materials and Methods}

Receptor protoplasts were isolated from habituated embryogenic suspension cells of 'Ruby Red' grapefruit (Citrus paradisi Macf.) and 'Murcott' tangor (Murcott Honey, Smith) (Citrus reticulata x Citrus sinensis). Donor protoplasts, for further microprotoplast production, were isolated from Swinglea glutinosa (Blanco) Merr. (Balsamocitrinae subtribe), a distant Citrus relative, in order to better distinguish donor pieces in the receptor genome background, which would be rather difficult if closer relatives were used due to greater similarities in their genomes. Swinglea glutinosa also presents a very distinct, heterochromatin-poor karyotype, and the smallest chromosomes known in the Aurantioideae subfamily (Guerra et al., 2000).

The habituated embryogenic suspension cells were produced from ovule-derived embryogenic callus and maintained in a two-week subculture cycle in liquid half-strength $\mathrm{H}+\mathrm{H}$ medium (Grosser \& Gmitter Junior, 1990) under constant agitation on a horizontal gyratory shaker (LabLine, USA) at $130 \mathrm{rpm}$, at room temperature and under constant illumination (two growth lux lamps of $20 \mathrm{~W}$ each - GE Lighting, Nela Park, Cleveland, OH, USA) (Grosser \& Gmitter Junior, 1990; Louzada et al., 2002).

Approximately $1 \mathrm{~g}$ of fresh weight drained cells (four to ten days after subculturing) were placed in a 5-cm diameter Petri dish with: i, $3 \mathrm{~mL}$ of $0.6 \mathrm{~mol} \mathrm{~L}^{-1}$ BH3 medium (Grosser \& Gmitter Junior, 1990) and $1 \mathrm{~mL}$ of filtered-sterilized enzyme solution 1\% cellulase R-10 (Karlan, Santa Rosa, CA, USA), $0.2 \%$ pectolyase $\mathrm{Y}-23$ (Karlan), $1 \%$ macerozyme $\mathrm{R}-10$ (Karlan), $0.024 \mathrm{~mol} \mathrm{~L}^{-1} \mathrm{CaCl}_{2}, 0.92 \mathrm{mmol} \mathrm{L}^{-1} \mathrm{NaH}_{2} \mathrm{PO}_{4}$, $6.15 \mathrm{mmol} \mathrm{L}^{-1}$ 2-[N-morpholino]ethanesulfonic acid (MES) (Sigma, Dallas, TX, USA), and $0.6 \mathrm{~mol} \mathrm{~L}^{-1}$ mannitol, pH 5.6 - for 'Ruby Red'; and ii, $3 \mathrm{~mL}$ of $0.7 \mathrm{~mol} \mathrm{~L}^{-1} \mathrm{BH} 3$ medium to $0.5 \mathrm{~mL}$ of the enzyme solution described above with $0.7 \mathrm{~mol} \mathrm{~L}^{-1}$ mannitol for 'Murcott' (Bona et al., 2009). Cells were digested overnight, in the dark, on a rocker platform (Bellco Glass, Inc, Vineland, NJ, USA), with six oscillations per minute. Protoplasts were separated from the debris by filtering through a sterile $45-\mu \mathrm{m}$ mesh stainless steel sieve, transferred to sterile $15-\mathrm{mL}$ centrifuge tubes, and centrifuged at $100 g_{\mathrm{n}}$ for $5 \mathrm{~min}$. The supernatant was removed and the protoplast pellet was carefully re-suspended in $5 \mathrm{~mL}$ of $25 \%$ sucrose. Mannitol (13\%) was slowly added to form a gradient, and the tubes were centrifuged for 5-10 min at $100 g_{n}$. The protoplast band formed was carefully removed with a Pasteur pipette and transferred to clean tubes. Protoplasts were washed with $5 \mathrm{~mL}$ of liquid $\mathrm{BH} 3$ medium and centrifuged for $5 \mathrm{~min}$ at $100 \mathrm{~g}_{\mathrm{n}}$. Protoplast pellets were diluted to approximately $1 \times 10^{6}$ protoplasts $\mathrm{mL}^{-1}$ in a small volume of BH3. For cell counting, a Bright-Line hematocytometer (Hausser Scientific, Horsham, PA, USA) was used.

Swinglea glutinosa suspension cells used for microprotoplast isolation had their media changed twice a week to maintain logarithmic cell growth. Microprotoplasts were isolated based on the citrus microprotoplast isolation protocol in Louzada et al. (2002). Briefly, a 7.2\% (w/v) mannitol to percoll (Amersham Pharmacy Biotech., Piscataway, NJ, USA) solution was placed in $14 \times 89-\mathrm{mm}$ centrifuge tubes (Beckman Instruments, Inc., Fullerton, CA, USA) 
and an iso-osmotic mannitol-percoll gradient was pre-formed by centrifuging it for $30 \mathrm{~min}$ at $100,000 \mathrm{~g}_{\mathrm{n}}$ in a swinging bucket rotor ( $\mathrm{SW} 41 \mathrm{Ti}$, Beckman Instruments, Inc., Fullerton, CA, USA). Protoplasts were placed on top of the mannitol-percoll solution, and tubes were centrifuged for two more hours at $100,000 g_{\mathrm{n}}$ at $20^{\circ} \mathrm{C}$. The bands of microprotoplasts formed were sequentially filtered once, twice, three and eventually four times through nylon sieves of 20, 15, 10 and 5- $\mu \mathrm{m}$ mesh (Small Parts, Inc., Miami Lakes, FL, USA), in order to isolate very small microprotoplasts. Small volumes of BH3 media were added to help the filtration process, and a sterile syringe plug was gently used to create pressure and push microprotoplasts through the $5 \mu \mathrm{m}$ mesh sieve. Filtered fractions were collected in mannitol-BH3 solution, and tubes were centrifuged for $10 \mathrm{~min}$ at $80 \mathrm{~g}_{\mathrm{n}}$. Supernatant was centrifuged for $10 \mathrm{~min}$ at $160 \mathrm{~g}_{\mathrm{n}}$ and the pellet was collected; supernatant was re-centrifuged and the new formed pellet was collected; supernatant was re-centrifuged for the third time and the newly formed pellet was collected. Hence, the first pellet contained heavier microprotoplasts than the second pellet of microprotoplasts, since heavier microprotoplasts would be the first ones to go to the bottom of the flask during centrifugation. The second centrifugation pellet, in its turn, was heavier than the third, which contained the lightest microprotoplasts, since these microprotoplasts would only go to the bottom of the flask after a third centrifugation. Pellets were re-suspended with approximately $1 \mathrm{~mL}$ of $\mathrm{BH} 3$, transferred to microfuge tubes sealed with parafilm and irradiated at the United States Department of Agriculture, Animal and Plant Health Inspection Service (USDA), Moore Air Base, Edinburg, TX, USA, with different gamma-ray (Gy) doses $(50,70,100$ or 200$)$ prior to fusion with receptor protoplasts.

Fusions were performed according to the Grosser \& Gmitter Junior (1990) polyethylene glycol (PEG) method. Irradiated S. glutinosa microprotoplasts were fused with non-irradiated 'Murcott' or 'Ruby Red' protoplasts in a proportion of approximately $3: 1$. The fusion combinations performed and the nomenclature used for the formed calli were: 'Ruby Red' protoplasts +50 Gy S. glutinosa microprotoplasts from the first pellet (H1); 'Ruby Red' protoplasts +70 Gy $S$. glutinosa microprotoplasts from the first (H2), second (H3) and third pellet (H4); 'Ruby Red' protoplasts $+200 \mathrm{~Gy}$ S. glutinosa microprotoplasts from the first (H5) and second (H6) pellets mixed together; and 'Murcott' protoplasts +100 Gy S. glutinosa microprotoplasts from the first pellet (H7).

In order to confirm the presence of pieces of S. glutinosa in the 'Ruby Red' and 'Murcott' genomes, calluses derived from all the performed fusions were evaluated by amplified fragment-length polymorphism (AFLP) and Southern dot-blot analyses. DNA was isolated from callus or suspension cells from both donor and receptor species, and from calli produced from the microprotoplast + protoplast fusions using DNeasy Plant Mini kit (Qiagen, Valencia, CA, USA). Briefly, calluses and drained suspension cells were ground in liquid nitrogen in a nuclease-free, sterile mortar until a paste was formed. Approximately $100 \mathrm{mg}$ of the paste was put into a sterile $2-\mathrm{mL}$ microfuge tube with $400 \mu \mathrm{L}$ of buffer AP1 and $8 \mu \mathrm{L}$ of RNase A stock solution (100 $\left.\mathrm{mg} \mathrm{mL}^{-1}\right)$. Tubes were incubated at $37^{\circ} \mathrm{C}$ over a rocker platform for $30 \mathrm{~min}$ plus $10 \mathrm{~min}$ at $65^{\circ} \mathrm{C}$. The tubes were mixed three times during incubation. One hundred and thirty microliters of buffer AP2 were added and incubated on ice for $5 \mathrm{~min}$ and centrifuged for $5 \mathrm{~min}$ at $20,000 \mathrm{~g}_{\mathrm{n}}$. The lysate was applied to a QIAshredder mini spin column in a 2-mL collection tube and centrifuged at 20,000 $g_{n}$ for $2 \mathrm{~min}$. The flow-through was transferred, without disturbing the cell-debris pellet, to a $2-\mathrm{mL}$ tube, and 1.5 times the volume of the lysate of AP3/E buffer was added and mixed by pippeting. The mix was filtered in a DNeasy mini spin column by centrifuging it for $1 \mathrm{~min}$ at $6,000 \mathrm{~g}_{\mathrm{n}}$, and the flow-through was discarded. The column was placed in a clean tube, $500 \mu \mathrm{L}$ of buffer AW were added, and columns were centrifuged for $1 \mathrm{~min}$ at $6,000 \mathrm{~g}_{\mathrm{n}}$. The flow-through was discarded, additional $500 \mu \mathrm{L}$ of buffer AW was added, and the columns were centrifuged for $2 \mathrm{~min}$ at $20,000 \mathrm{~g}_{\mathrm{n}}$ to dry the membrane. The columns were transferred to $1.5-\mathrm{mL}$ microfuge tubes, $50 \mu \mathrm{L}$ of $\mathrm{AE}$ elution buffer were added to the membrane, then incubated at room temperature for $5 \mathrm{~min}$ and centrifuged at $6,000 g_{n}$ for 1 min to elute the DNA. This step was repeated twice. Two microliters of DNA from both elutions were diluted in $98 \mu \mathrm{L}$ of nuclease free water, and purity and concentrations were measured in an UV/visible spectrophotometer (Amersham Biosciences, Piscataway, NJ, USA). Extracted DNA was stored at $-20^{\circ} \mathrm{C}$. 
DNA for dot blotting was extracted from calluses produced from the microprotoplast-protoplast fusion and from the donor and receptor parents. Target DNA blotting followed the protocol of the Bio-Dot Microfiltration Apparatus (Bio-Rad, Hercules, CA, USA) and nucleic acid labeling/detection followed the AlkPhos Direct method (Amersham Biosciences) using a Zeta-probe blotting membrane (Bio-Rad) instead of a Hybond- $\mathrm{N}^{+}$nylon transfer membrane.

AFLP analysis was performed in a 4,300 DNA analyzer (Li-Cor, Inc. Lincoln, NE, USA) using the IRDye Fluorescent AFLP Kit (Li-Cor, Inc.). Licor kit EcoRI labeled primers and unlabeled MseI primers were tested in the following MseI unlabeled - EcoR1 labeled primer combinations: $\mathrm{CAG}$ with ACC, AGG or CAG; CAA with ACA, AGG or CAA; CA with ACA, AGG, AAC, ACT, AAG or ACC; AC with AAC; and CT with ACT, ACA, ACG, AAC, AGC, AAG, AGG, ACC, or CAT.

\section{Results and Discussion}

Swinglea glutinosa microprotoplasts were easily isolated, as reported previously by Louzada et al. (2002), and very small microprotoplasts containing one to three chromosomes (Figure 1) were efficiently recovered.

The ability to use a wide range of irradiation (50 to $200 \mathrm{~Gy}$ ) is of interest, because modulation of irradiation dosage may be used, as stated by Kalavacharla etal.(2006), to construct maps with varying levels of resolution, as different protoplast fusion events may create a multitude of different hybrid cell panels which may be arranged to cover a whole genome in a radiation map.

Cell colonies were successfully formed and AFLP markers have proved to be highly polymorphic and reproducible, as reported by James et al. (2003), and gel replication confirmed results. That was expected, since AFLP has been useful in detecting chromosome losses and in revealing more information about hybridity in somatic hybrids, because it provides reliable markers, high resolution and efficiency (Fu et al., 2004). Vos et al. (1995) and Fu et al. (2004) also considered AFLP to be robust and reliable against methylation alterations, which is important, since habituated embryogenic cell suspensions are regarded to be more susceptible to methylation. Shaked et al. (2001) had already put the AFLP technique to the proof by testing it with methylation-sensitive amplification polymorphism (MASP) to obtain the quantitative estimate of the timing and frequency of allopolyploid-associated genetic and epigenetic response of wheat in wide hybridizations, and obtained reproducible patterns of elimination which were proven not to be attributed to heterozygosity or methylation, concluding that AFLP is a high-throughput mean to assess the induction of genomic rearrangements. Furthermore, genetic and epigenetic evaluations of citrus calluses performed by Hao et al. (2004) using MSAP suggested that the ploidy level remains stable during long in vitro periods.

Diverse AFLP bands from both parents were visible with diverse enzyme combinations. It was possible to observe exclusive bands from the receptors ('Ruby Red' and 'Murcott'), but complementary bands were also visible, indicating a similar genetic constitution between $S$. glutinosa and the Citrus receptors in spite of their genetic distance. Nevertheless, $S$. glutinosa bands were the focus of the fusion, because their presence in the 'Ruby Red' and 'Murcott' receptor genomes, which had their protoplasts neither irradiated nor treated with microtubule toxins. This indicates that the receptor DNA strand was, indeed, disrupted by the insertion of small pieces of the donor DNA, since the microprotoplasts containing few chromosomes

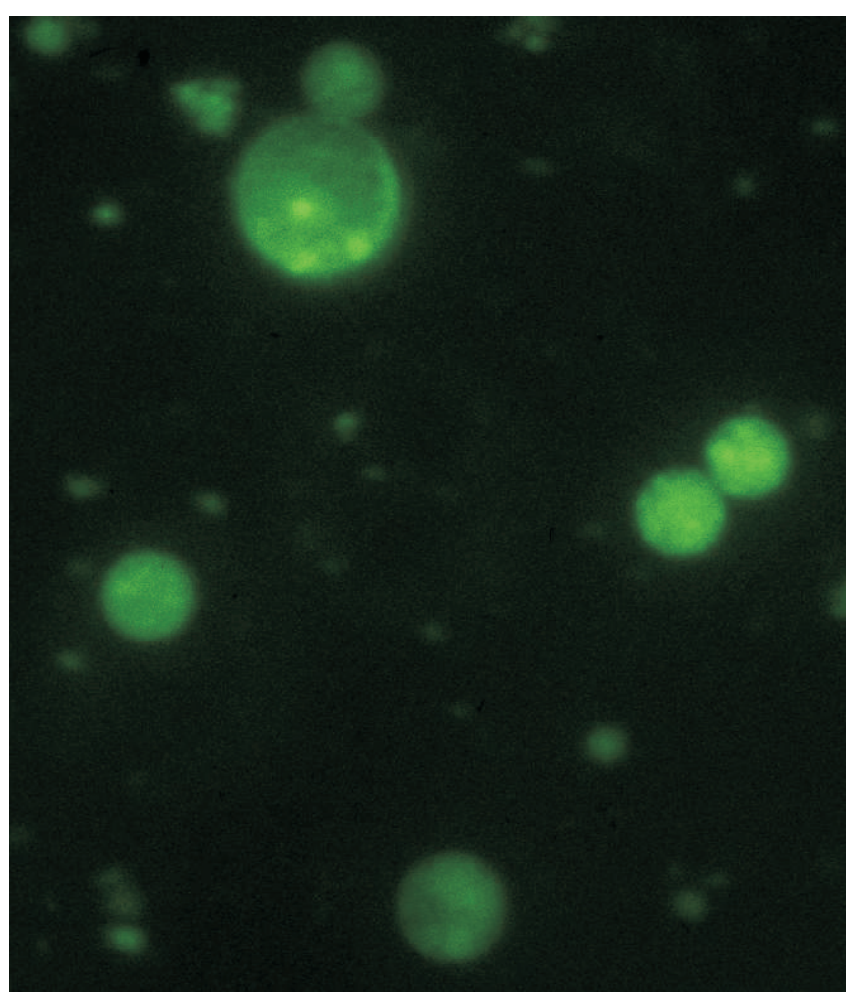

Figure 1. Swinglea glutinosa microprotoplasts containing few (1-3) chromosomes, stained with acridine orange and visualized with Nikon EF-4 triple-band filter. 
(Figure 1) had been exposed to different doses of gamma radiation. Lack of receptor DNA bands and few newly appeared bands in some hybrid lines were probably results of donor insertions into the receptor DNA strand in a position which changed the sequence of DNA bases and modified sites which would be recognized by the cutting enzyme. Such extra bands could be misread as artifacts due to DNA methylation, which is believed to occur in long-term cultured cells. However, AFLP is regarded to be robust against methylation (Vos et al., 1995; Fu et al., 2004; Hao et al., 2004). Furthermore, such newly formed bands may increase the power of cell panel creation, since diversity of panels is created by the innumerable possibilities of combining different radiation doses, for different fusions, with different combinations of cutting enzymes.

The best AFLP enzyme combinations for the different cell lines analyzed are presented next: cell lines produced from 'Murcott' protoplasts + irradiated $S$. glutinosa microprotoplasts fusions revealed complementary bands from both parents, 'Murcott' (M) and S. glutinosa (SW), in the hybrid cell line H7. The best primer combinations were MseI-AC + EcoRI-AAC (Figure $2 \mathrm{~A}$ ) and MseI-CT + EcoRI-AAC (Figure $2 \mathrm{~B}$ and $\mathrm{C}$ ).

Cell lines produced from 'Ruby Red' protoplasts + irradiated S. glutinosa microprotoplasts

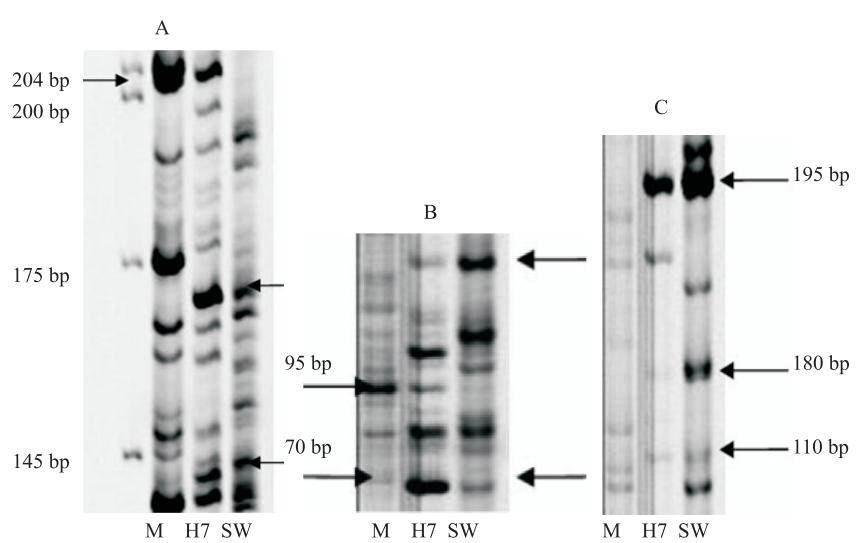

Figure 2. Complementary bands from 'Murcott' tangor (Citrus reticulata x Citrus sinensis) (M) and Swinglea glutinosa (SW) parents observed in hybrid cell line H7 (fusion combination of 'Murcot' protoplasts + $100 \mathrm{~Gy}$ $S$. glutinosa microprotoplasts from the first pellet) with the $M s e I-A C+E c o$ RI-AAC (A) and MseI-CT + EcoRI-AAC primer combinations $(\mathrm{B}, \mathrm{C})$. fusions included AFLP bands from both parents, 'Ruby Red' (RR) and S. glutinosa (SW). The MseI-CAA + EcoRI-AGG primer combination showed evidence of $S$. glutinosa DNA in all fusion samples (Figure 3). The MseI-CT + EcoRI-ACT primer combination showed evidence of S. glutinosa DNA in H2, H3, H4, H5 and H6 (Figure 4). $M s e I-C A+E c o$ RI-ACC, MseI-CT + EcoRI-ACT, and MseI-CA + EcoRI-ACT also showed evidence of S. glutinosa DNA.

The presence of donor genomein calluses arising from fusions of the irradiated $S$. glutinosa microprotoplasts with 'Ruby Red' and 'Murcott' may indicate that rearranged $S$. glutinosa chromosomes were retained or that $S$. glutinosa DNA was inserted or translocated into chromosomes of 'Ruby Red' and 'Murcott'. Wardrop et al. (2002) fused transgenic barley protoplasts with tobacco and obtained insertions after donor protoplast exposure up to $50 \mathrm{~Gy}$. Although they generated large numbers of putative hybrids, doses higher than 50 Gy caused no callus colony formation. In their study,

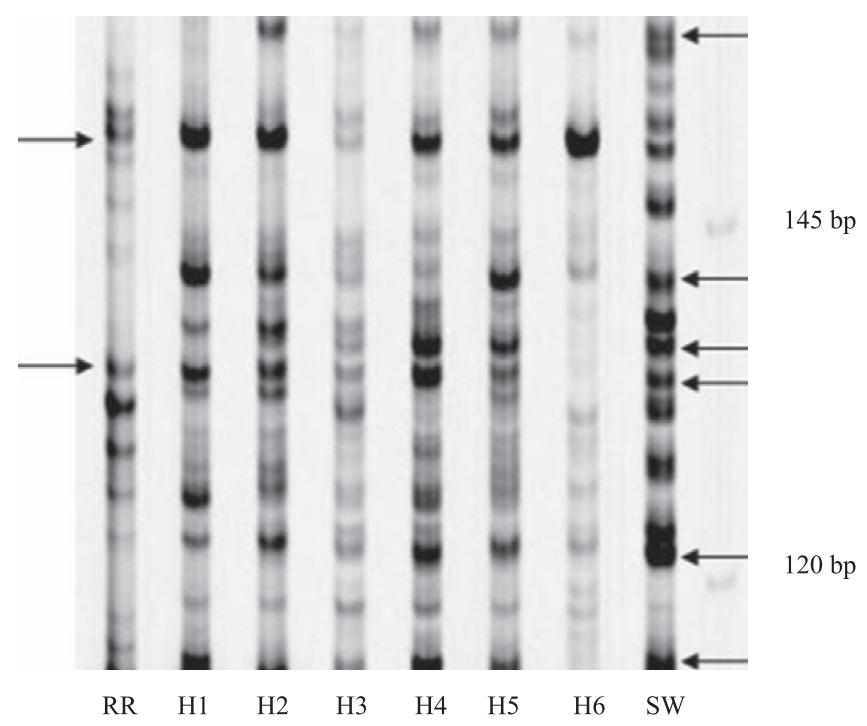

Figure 3. Bands from 'Ruby Red' grapefruit (Citrus paradisi) (RR) and Swingleaglutinosa (SW) parents in the AFLPanalysis of hybrid cell lines H1 to H6-fusion combinations of 'Ruby Red' protoplasts +50 Gy $S$. glutinosa microprotoplasts from the first pellet (H1); 'Ruby Red' protoplasts + 70 Gy S. glutinosa microprotoplasts from the first (H2), second (H3) and third pellet (H4); 'Ruby Red' protoplasts + 200 Gy S. glutinosa microprotoplasts from the first (H5) and second (H6) pellets mixed together - with the MseI-CAA + EcoRI-AGG primer combination. 
validation of the co-retention of physically linked markers was obtained by analysis of a pair of closely linked barley markers which were either both present or absent in the barley-tobacco hybrids, consistent with tight linkage, demonstrating the utility of the panel for exploitation in mapping procedures. Retention was also achieved by Kalavacharla et al. (2006), who presented a high-resolution radiation hybrid map of wheat chromosome 1D, and by Kynast et al. (2002), who demonstrated the use of maize radiation hybrid lines for physical mapping, and related genetic map distances to physical chromosome segment sizes.

The cell lines produced herein presented insertions with different enzyme combinations, possibly due to the smaller chromosome pieces of the donor microprotoplasts induced by the irradiation doses. This may be important as a first step for future radiation mapping of Citrus. In addition to the prospect of genome analysis, this research may facilitate efficient chromosome/DNA transfer across narrow or very wide genetic "distances", and bring to light many interesting possibilities for breeding, biosynthetic pathways, disease resistance, and genomics research as, according to Zhdanova (2002), radiation hybrid panels can be used to map individual chromosomes or an entire genome.

Cell panels can be formed fast due to the smaller amount of genetic material transferred by the irradiated microprotoplasts. Wardrop et al. (2002) observed that the traditional hybrid callus production process in plants (protoplast-protoplast fusion) was less efficient than in techniques used to generate mammalian panels, and had to make many fusions to form their panels. This may represent another advantage of using microprotoplasts instead of protoplasts, as smaller pieces of donor DNA may be more easily inserted in the receptor's genome (Yemets \& Blume, 2003) and are less prone to be repelled in further cell divisions. Such small pieces may be present in the receptor genome as small donor insertions or translocations caused by the massive irradiation doses, as retention of highly rearranged donor chromosomes into the receptor genome is possible.

That is why the importance of higher performance techniques, such as fluorescent in situ hybridization (FISH) and genomic in situ hybridization (GISH), is emphasized as means of quickly providing confirmation of introgression and stability through divisions. AFLPs could be used to pick out bacterial artificial chromosome (BAC) or cosmid to FISH. Such procedures would provide a direct and visual method for effective number and position determination of the donor chromosome pieces, making possible the visualization of alien material (Fu et al., 2004). GISH would allow pinpointing the exact location of donor sequences into the receptor genomes and help to select the panel members. It was successfully applied to identify citrus somatic hybrids by Fu et al. (2004) and Guo et al. (2004).

As opposed to the AFLP analysis, the Southern dot-blot analysis was not considered very conclusive in this work because, even though the presence of $S$. glutinosa could be detected on the dots, it was not visually ideal.
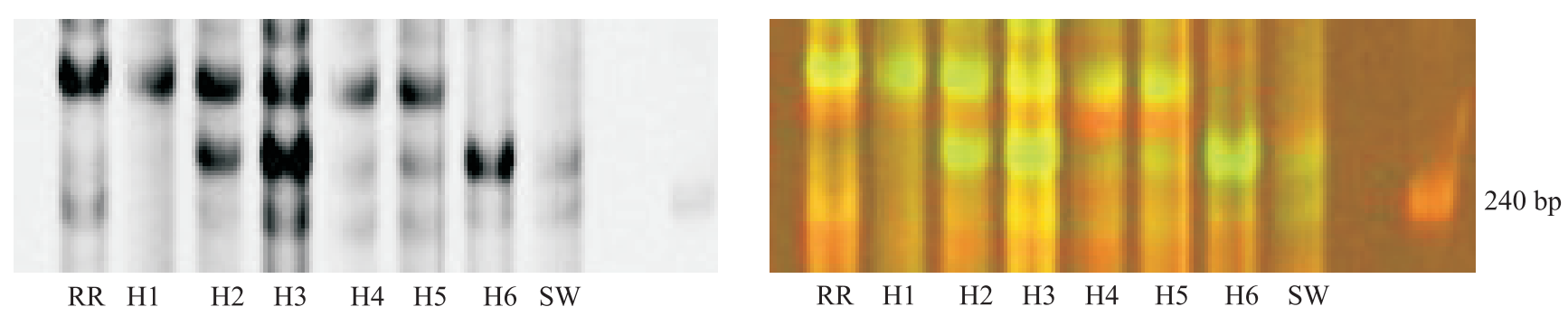

Figure 4. Bands (in black and white and in color) from both 'Ruby Red' grapefruit (Citrus paradisi) (RR) and Swinglea glutinosa (SW) parents in the AFLP analysis of hybrid cell lines H1 to H6 - fusion combinations of 'Ruby Red' protoplasts +50 Gy S. glutinosa microprotoplasts from the first pellet (H1); 'Ruby Red' protoplasts +70 Gy S. glutinosa microprotoplasts from the first (H2), second (H3) and third pellet (H4); 'Ruby Red' protoplasts $+200 \mathrm{~Gy}$ S. glutinosa microprotoplasts from the first (H5) and second (H6) pellets mixed together - with the MseI-CT + EcoRI-ACT primer combination. The two independent detection channels (green and red) use separate lasers to eliminate errors due to fluorescence overlap. 


\section{Conclusions}

1. Combination of asymmetric somatic hybridization (donor-recipient fusion or gamma fusion) to microprotoplast-mediated chromosome transfer (MMCT) in citrus is successfully performed.

2. Fusion of irradiated Swinglea glutinosa microprotoplasts with 'Ruby Red' grapefruit (Citrus paradisi) or 'Murcott' tangor (Citrus reticulata $\mathrm{x}$ Citrus sinensis) protoplasts produce hybrid cell lines.

3. Swinglea glutinosa chromosome pieces are inserted in the receptor genomes, as confirmed by AFLP analyses.

4. The technique described may be used for the development of a radiation map in citrus.

\section{Acknowledgements}

To Jude W. Grosser (Citrus Research and Education Center, University of Florida, Lake Alfred, USA), for producing and providing ovule-derived embryogenic callus, and to Coordenação de Aperfeiçoamento de Pessoal de Nível Superior, for a Fulbright scholarship to the first author.

\section{References}

BONA, C.M. de; GOULD, J.H.; MILLER JUNIOR, J.C.; STELLY, D.; LOUZADA, E.S. Citrus asymmetric somatic hybrids produced via fusion of gamma-irradiated and iodoacetamide-treated protoplasts. Pesquisa Agropecuária Brasileira, v.44, p.454-462, 2009.

COX, D.R.; BURMEISTER, M.; PRICE, E.R.; KIM, S.; MYERS, R.M. Radiation hybrid mapping: a somatic cell genetic method for constructing high-resolution maps of mammalian chromosomes. Science, v.250, p.245-250, 1990.

FOURNIER, R.E.; RUDDLE, F.H. Stable association of the human transgenome and host murine chromosomes demonstrated with trispecific microcell hybrids. Proceedings of the National Academy of Sciences, v.74, p.3937-3941, 1977.

FU, C.H.; CHEN, C.L.; GUO, W.W.; DENG, X.X. GISH, AFLP and PCR-RFLP analysis of an intergeneric somatic hybrid combining Goutou sour orange and Poncirus trifoliata. Plant Cell Reports, v.23, p.391-396, 2004.

GAO, W.X.; CHEN, Z.J.; YU, J.Z.; KOHEL, R.J.; WOMACK, J.E.; STELLY, D.M. Wide-cross whole-genome radiation hybrid mapping of the cotton (Gossypium barbadense L.) genome. Molecular Genetics and Genomics, v.275, p.105-113, 2006.

GAO, W.X.; CHEN, Z.J.; YU, J.Z.; RASKA, D.; KOHEL, R.J.; WOMACK, J.E.; STELLY, D.M. Wide-cross whole-genome radiation hybrid mapping of cotton (Gossypium hirsutum L.). Genetics, v.167, p.1317-1329, 2004.

GROSSER, J.W.; GMITTER JUNIOR, F.G. Protoplast fusion and citrus improvement. Plant Breeding Reviews, v.8, p.339-374, 1990.

GUERRA, M.; SANTOS, K.G.B. dos; SILVA, A.E.B.E.; EHRENDORFER, F. Heterochromatin banding patterns in Rutaceae-Aurantioideae-a case of parallel chromosomal evolution. American Journal of Botany, v.87, p.735-747, 2000.

GUO, W.W.; CHENG, Y.J.; CHEN, C.L.; FU, C.H.; DENG, X.X. Molecular characterization of several intergeneric somatic hybrids between Citrus and its related genera. Acta Horticulturae, v.632, p.259-264, 2004.

HAO, Y.J.; WENG, X.P.; DENG, X.X. Genetic and epigenetic evaluations of citrus calluses recovered from slow-growth culture. Journal of Plant Physiology, v.161, p.479-484, 2004.

JAMES, C.M.; LESEMANN, S.S.; DOWN, G.J. Modified AFLP analysis method for species with small genomes. Plant Molecular Biology Reporter, v.21, p.303-307, 2003.

KALAVACHARLA, V.; HOSSAIN, K.; GU, Y.; RIERA-LIZARAZU, O.; VALES, M.I.; BHAMIDIMARRI, S.; GONZALEZ-HERNANDEZ, J.L.; MAAN, S.S.; KIANIAN, S.F. High-resolution radiation hybrid map of wheat chromosome 1D. Genetics, v.173, p.1089-1099, 2006.

KYNAST, R.G.; OKAGAKI, R.J.; RINES, H.W.; PHILLIPS, R.L. Maize individualized chromosome and derived radiation hybrid lines and their use in functional genomics. Functional and Integrative Genomics, v.2, p.60-69, 2002.

LOUZADA, E.S.; DEL RIO, H.S.; XIA, D.; MORAN-MIRABAL, J.M. Preparation and fusion of Citrus sp. microprotoplasts. Journal of the American Society for Horticultural Science, v.127, p.484-488, 2002.

MASOUDI-NEJAD, A.; NASUDA, S.; BIHOREAU, M.T.; WAUGHA, R.; ENDO, T.R. An alternative to radiation hybrid mapping for large-scale genome analysis in barley. Molecular Genetics and Genomics, v.274, p.589-5946, 2005.

RAMULU, K.S.; DIJKHUIS, P.; RUTGERS, E.; BLASS, J.; KRENS, F.A.; DONS, J.J.; COLIJN-HOOYMANS, C.M.; VERHOEVEN, H.A. Microprotoplast-mediated transfer of single specific chromosomes between sexually incompatible plants. Genome, v.39, p.921-933, 1996 b.

RAMULU, K.S.; DIJKHUIS, P.; RUTGERS, E.; BLAAS, J.; KRENS, F.A.; VERBEEK, W.H.J.; COLIJN-HOOYMANS, C.M.; VERHOEVEN, H.A. Intergeneric transfer of a partial genome and direct production of monosomic addition plants by microprotoplast fusion. Theoretical and Applied Genetics, v.92, p.316-325, 1996a.

RIERA-LIZARAZU, O.; VALES, M.I.; ANANIEV, E.V.; RINES, H.W.; PHILLIPS, R.L. Production and characterization of maize chromosome hybrids derived from an oat-maize addition line. Genetics, v.156, p.327-339, 2000.

SHAKED, H.; KASHKUSH, K.; OZKAN, H.; FELDMAN, M.; LEVY, A.A. Sequence elimination and cytosine methylation are rapid and reproducible responses of the genome to wide 
hybridization and allopolyploidy in wheat. Plant Cell, v.13, p.1749-1759, 2001.

TALON, M.; GMITTERJUNIOR, F.G.Citrus genomics. International Journal of Plant Genomics, v.2008, p.528-361, 2008.

VOS, P.; HOGERS, R.; BLEEKER, M.; REIJANS, M.; VAN DE LEE, T.; HORNES, M.; FRIJTERS, A.; POT, J.; PELEMAN, J.; KUIPER, M.; ZABEAU, M. AFLP: a new technique for DNA fingerprinting. Nucleic Acids Research, v.23, p.4407-4414, 1995.

WARDROP, J.; SNAPE, J.; POWELL, W.; MACHRAY, C. Constructing plant radiation hybrid panels. Plant Journal, v.31, p.223-228, 2002.

WIJBRANDI, J. Isolation and characterization of somatic hybrids between Lycopersicon esculentum and
Lycopersicon peruvianum. 1989. 1320p. Thesis (Doctor) Wageningen University, Netherlands.

YEMETS, A.I.; BLUME, Y.B. Microprotoplasts as an efficient technique for chromosome transfer of single chromosomes between incompatible plant species. Cytology and Genetics, v.37, p.38-48, 2003.

YERLE, M.; LAHBIB-MANSAIS, Y.; ROBIC, A.; MOMPART, F.; DELCROS, C.; MILAN, D. Radiation hybrids: a tool for high-resolution mapping. Animal Science Papers and Reports, v.22, p.77-81, 2004.

ZHANG, Q.; LIU, J.; DENG, X. Isolation of microprotoplasts from a partially synchronized suspension culture of Citrus unshiu. Journal of Plant Physiology, v.163, p.1185-1192, 2006.

ZHDANOVA, N.S. Genome radiation hybrid mapping: summary and future direction. Russian Journal of Genetics, v.38, p.475-485, 2002.

Received on August 10, 2009 and accepted on November 27, 2009 